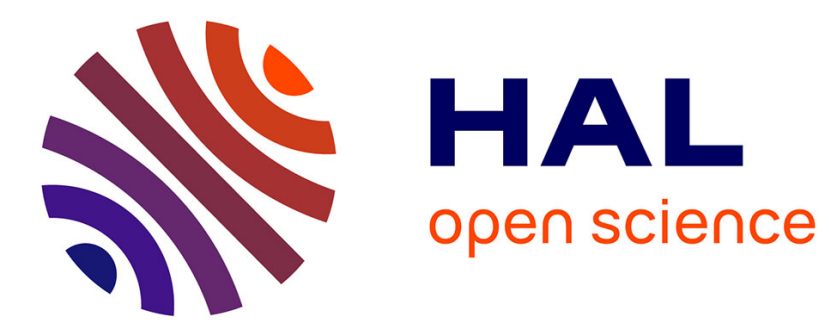

\title{
Muslim Feminist, Media Sensation, and Religious Entrepreneur: Aminata Kane Koné as a Figure of Success in Côte d'Ivoire
}

Frédérick Madore

\section{- To cite this version:}

Frédérick Madore. Muslim Feminist, Media Sensation, and Religious Entrepreneur: Aminata Kane Koné as a Figure of Success in Côte d'Ivoire. Africa Today, 2020, 67 (2-3), pp.17-38. 10.2979/africatoday.67.2-3.02 . halshs-03161143

\section{HAL Id: halshs-03161143 \\ https://shs.hal.science/halshs-03161143}

Submitted on 5 Mar 2021

HAL is a multi-disciplinary open access archive for the deposit and dissemination of scientific research documents, whether they are published or not. The documents may come from teaching and research institutions in France or abroad, or from public or private research centers.
L'archive ouverte pluridisciplinaire HAL, est destinée au dépôt et à la diffusion de documents scientifiques de niveau recherche, publiés ou non, émanant des établissements d'enseignement et de recherche français ou étrangers, des laboratoires publics ou privés. 


\title{
Muslim Feminist, Media Sensation, and Religious Entrepreneur: Aminata Kane Koné as a Figure of Success in Côte d'Ivoire
}

Frédérick MADORE

\begin{abstract}
This article analyzes the career path of Aminata Kane Koné, a highly educated Ivorian Muslim woman, who has emerged as a female figure of success. A prominent activist of the Association des Élèves et Étudiants Musulmans de Côte d'Ivoire in the 2000s, she has become a self-made religious entrepreneur through media and social initiatives. She has overcome social constraints to establish herself as a highly mediatized Muslim public intellectual, influential not only in Islamic circles, but within the broader society. Her case illustrates ways in which relationships between gender and Islamic authority are changing in West Africa. She embodies a uniquely hybrid feminism, influenced by her secular education and her Muslim faith.
\end{abstract}

\section{Introduction}

In Côte d'Ivoire, Islam has grown greatly since the 1950s. This religion accounted for around 20 percent of the population at the time of independence (Miran 2006, 61), but now accounts for 43 percent of the population, compared to 34 percent for Christians, according to 2014 census data (Ibrahima 2014). Researchers have shown considerable interest in Islam in predominantly Muslim countries in West Africa, but they have left Côte d'Ivoire relatively understudied. Nevertheless, a growing body of the literature has pointed out the diverse, changing, and contested Islamic field in Côte d'Ivoire, as illustrated by the rise of a modernist and reformist elite (Miran 2006), the recent dynamism of Salafism (Madore 2016a), and a Sufi revival (Binaté 2017a), with the participation of youth and women in neighborhood-based Islamic associations (LeBlanc 1999, 2000, 2007). Since 2011, when Alassane Ouattara, the country’s first Muslim president, was inaugurated, prominent 
imams and Muslim leaders of Abidjan have developed close relations with the ruling regime (MiranGuyon 2017).

In recent years, several studies have highlighted the proliferation of locally initiated Islamic nongovernmental organizations (NGOs) (Binaté 2016), including women-led ones (LeBlanc 2014, 2016), since the failed putsch of September 19, 2002, which divided Côte d'Ivoire into a southern region under the authority of President Laurent Gbagbo and a northern one controlled by insurgents. During the subsequent civil war, various humanitarian initiatives supported by international funding agencies filled the void left by crumbling state social services (Akindès and Troit 2017). Young Muslims in Côte d'Ivoire and elsewhere in West Africa are less engaged in Islamic activism than the 1990 s generation while becoming more interested in personal fulfillment and ideas of religious entrepreneurship, which often involve humanitarian activities (LeBlanc 2012; Soares and LeBlanc 2015).

While Marie Nathalie LeBlanc has focused on the entrepreneurship of "ordinary Muslims," mostly in Bouaké, ${ }^{1}$ this article analyzes the career path of Aminata Kane Koné, a highly and secularly educated Ivorian Muslim woman in Abidjan, who has emerged as a female "figure of success" (Banégas and Warnier 2001). Over the last years, President Ouattara has repeatedly stressed the importance of fostering in Côte d'Ivoire an entrepreneurial culture for improving youth employment (Akindès 2017, 8-10); however, the youth, and especially women, still face a daunting labor market, despite impressive GDP growth since 2011 (Lefeuvre et al. 2017). Aminata Kane Koné, a prominent activist of the Association des Élèves et Étudiants Musulmans de Côte d'Ivoire (Association of Muslim Students of Côte d'Ivoire, or AEEMCI) in the 2000s, has become a self-made religious entrepreneur through media and social entrepreneurship. She has overcome social constraints to establish herself as a highly mediatized "Muslim public intellectual” (Soares 2016), influential not only in Islamic circles, but within the broader Ivorian society. She stands as a role model for many 
Muslim women aspiring to achieve her success. Her story exemplifies alternative trajectories for upward social mobility in African societies in a context where the possibilities are still constrained. Much of the research on entrepreneurship in Africa has traditionally focused on the economic sector. In a context of dramatic socioeconomic changes following the imposition of structural-adjustment programs from the 1980s-deregulation, liberalization, privatization, currency devaluation, massive underemployment—several studies have examined new entrepreneurial strategies across the continent (e.g., Jalloh and Falola 2002). Some authors have analyzed African entrepreneurs in the development sector, where they act as brokers for international aid (Bierschenk, Chauveau, and Olivier de Sardan 2000), and in digital enterprises (Taura, Bolat, and Madichie 2019). Increasingly, numerous publications investigate different forms of entrepreneurship beyond economic ventures. Banégas and Warnier (2001) have stressed the entrepreneurial abilities of Africans who have followed alternative paths to success through a moral economy of cunning and débrouille ("survival practices"). Other studies have focused on the "cultural entrepreneurs" active in media, education, culture, or religious sectors (Röschenthaler and Schulz 2015).

Recently, interest in how religion and entrepreneurship intersect has increased (Fourchard, Mary, and Otayek 2005), especially with the burgeoning of Pentecostal churches that preach the prosperity gospel (Freeman 2012; Lauterbach 2015; Marshall 2009). Regarding Islam, Patrick Haenni (2005) has popularized the notion of religious entrepreneurship, as well as subsequent studies on Muslim entrepreneurs inscribing their business into the rhetoric of the "common good" (Osella and Osella 2009). Several researchers have examined the Senegalese Murid trade diaspora (e.g., Diouf and Rendall 2000). Benjamin Soares (2005) has analyzed the "prayer economy" in Mali with the development of a "fee-for-service religion" by showing how Muslim saints have commodified their spiritual power. In another study, he has pointed out the rise of new religious entrepreneursmarabouts d'affaires — who cultivate an ethic of entrepreneurship in the era of neoliberal reforms 
(Soares 2017). Abdoulaye Sounaye (2013, 2015), studying the Nigerien case, has claimed that religious entrepreneurship has provided opportunities for young Muslims to acquire authority and build communities of followers by initiating projects to serve the community. Several women in Senegalese Sufi movements are becoming involved in development and entrepreneurial initiatives (Hill 2017, 2018).

In this article, I employ Ute Röschenthaler and Dorothea Schulz's definition of the "cultural entrepreneur" $(2015,1)$, which encompass religious and other kinds of entrepreneurship:

We use "entrepreneur" as a concept and a heuristic term to point to the plethora of engagements by which social actors in African societies deal with the constraints and opportunities generated by the contemporary moment. ... The term "cultural entrepreneurs" refers to individuals who quickly perceive the chances of the moment and seize novel opportunities to initiate new forms of generating income in the realm of cultural production.

The rise of Aminata Kane Koné as a female figure of success occurred in a period of sociopolitical instability in Côte d'Ivoire but, at the same time, of opportunities with the development of Islamic and digital media. She is not a typical religious entrepreneur in the sense that she has not converted her economic resources into religious capital, nor accumulated great wealth through Islamic-related activities; instead, she exemplifies entrepreneurial innovation by branding herself through media and social initiatives. She cultivates the image of a young and pious Muslim public intellectual who demonstrates religious and entrepreneurial leadership.

Aminata Kane Koné's life trajectory illustrates the ways in which the relationships between gender and Islamic authority are changing in West Africa (Frede and Hill 2014); more specifically, it raises the issue of Islamic feminism, which has remained largely unexamined (e.g., Saint-Lary 2019, 243-69). Despite widespread resistance to the term feminism as connoting Western and secular women's activism, that does not necessarily mean Muslim women disagree with the idea that they 
should have the same political, social, and economic rights as men. For instance, Aminata Kane Koné positions herself as a feminist, even if she does not explicitly label herself as such. She embodies a hybrid feminism of her own, influenced by her secular educational background and her Muslim faith. As pointed out by Margot Badran, Islamic feminism and secular feminism are not “hermetic entities” (2009, 2). In a globalized world, Muslim women activists are likely to combine religious and secular frameworks to address rights and gender issues (Hafez 2011; Rinaldo 2013; Schielke 2010).

The article is based on empirical data collected in the course of fieldwork conducted in Abidjan during November 2014 and April 2015. The research included participant-observation and interviews with different cohorts of AEEMCI leaders and activists, men and women, including one lengthy interview with Aminata Kane Koné (2015). It draws on the national media ${ }^{2}$ and the Islamic press, ${ }^{3}$ as well as social media posts, interviews, and talks by Aminata Kane Koné posted online. The article begins by examining the role of women in the AEEMCI since its creation in the 1970s. If the association provided many young women with an opportunity to engage in activism alongside their male peers, AEEMCI programming tended to reproduce patriarchal power structures. The second part discusses how Aminata Kane Koné, who joined the AEEMCI in 1998, adopted a more radical approach to women's equality and emancipation within Islam than had her predecessors from the beginning of the 1990s. She has used Islam to empower other women and promote self-realization, financial independence, and professional opportunities for women. The third part analyzes her emergence as a media entrepreneur. Her activism caught the attention of management at the Islamic radio station $\mathrm{Al}$ Bayane, where she became a media sensation for more than ten years. Her ability to attract new followers as an opinion leader on social media contributed to her rise as a female Muslim public intellectual. The final section highlights how she gained attention from the US embassy in Côte d'Ivoire while pursuing various social projects. The symbolic and financial recognition she 
received from the American government for her advocacy work for Muslim women's rights and youth entrepreneurship has reinforced her image as a female figure of success.

\section{Limited Role for Women in the AEEMCI (1970-2000): Preparing Food and Drink for Attendees?}

In the early 1970s, Francophone Muslim students educated in the école du Blanc-the Westernoriented public school system—-began looking for ways to learn more about their religion and to reclaim their Islamic identity. Following the example of Christian students, they created informal Islamic groups at various educational institutions (Fraternité Matin 1974). In January 1972, students at the Universite de Cocody organized an assembly that led to the creation of the AEEMCI, the country's first national Muslim youth association, which was officially recognized by the state in April 1979. Although AEEMCI can be described as reformist or modernist, it is not formally aligned with a specific Islamic current. Members like to describe it as a melting pot, open to all Muslim students, regardless of the branch of Islam they follow (Koné 2014). It focuses on explaining the tenets of Islam to students in French-language schools and universities.

The activities organized by the AEEMCI were adapted to an academic setting. They included evening classes, conferences, debates, seminars, film screenings, summer camps, Islamic cultural weeks, theater performances, and sporting events. In the 1970s and the 1980s, AEEMCI activists challenged negative stereotypes of Muslims. At the time, Ivorian media, as well as the country's secular and Christian elites, frequently portrayed Islam as a backward religion, dominated by superstitions. The AEEMCI responded by organizing conferences, debates, and talks that highlighted Muslim contributions to science, modernity, and economic development (Miran 2006, 295-346). Thanks to AEEMCI activities, Francophone Muslims began to be seen as legitimate interpreters of Islam. French emerged as a legitimate language for the development of Islam (MiranGuyon and Oyewolé 2015). 
Throughout the 1970s and 1980s, a notable number of girls participated in the religious educational activities organized by the AEEMCI. In addition to praying together, male and female students attended mixed-gender study sessions to deepen their Islamic knowledge. Such activities were often held in evenings, on weekends, or during school holidays. Nevertheless, the female members, despite their presence at various activities, played a decidedly marginal role in the organization during the period. This held true even in the case of activities focused on women's issues.

Consider the event held in December 1978 at the Williamsville Islamic Cultural Center in Abidjan. The female Muslim students of the Lycée Sainte-Marie had organized a dinner debate to discuss the place of Muslim girls in the modern world. A journalist assigned to cover the event applauded the organizers' initiative to discuss such a topical issue; however, the event proved disappointing: "the level of discussion, in the opinion of many, was not very impressive," and "the hostesses, too busy serving [food and drink], were not able to properly participate in the debate they themselves had organized" (Fraternité Matin 1978). ${ }^{4}$ Both invited speakers—who discussed young Muslim women's clothing, marriage prospects, and professional opportunities—were men.

In the late 1980s, the AEEMCI male leaders tried to address the association's problems with engaging female members. The president of the association at the time has explained how young women themselves were pushing for change: "The girls demanded a more active role and refused to continue being treated as second-class activists" (Doumbia 2015). The pressure for change led to the creation of Muslim Women's Days, a regular conference first held in 1987. That year's event focused on Muslim women's role in national development. The activity was modeled on the mixed-gender National Islamic Training Seminar, which had been held every summer since 1982; however, holding an event exclusively for female activists gave the women an opportunity to discuss their own issues without being drowned out by male voices. Meanwhile, the AEEMCI amended its statutes to 
reserve one of its three vice-presidential positions for a female member, who would be "in charge of women's affairs" (Doumbia 2015).

When the AEEMCI held Muslim Women's Days for the second time in 1989, its communication officer explained that the event would allow younger female activists to exchange ideas with their married elders. She emphasized the need to "give the floor to our sisters to tackle contemporary problems, ... marriage, for example" (Fraternité Matin 1989a). Looking back on the event, the association's female vice president explained that it "should not be seen as a moment when sisters achieved autonomy in relation to their brothers, but simply as a time when all Muslim youth in Côte d'Ivoire sought to give women their rightful place in society, their proper attributes as defined in the Qur'an and the hadiths" (Fraternité Matin 1989b). In other words, the AEEMCI's female activists were not seeking to resist the patriarchal gender order or to reinterpret Islamic dogmas with the aim of reshaping gender relations; they largely accepted their assigned roles within the association. Their activities reflected a conscious desire to better conform to Islamic teachingsself-fashioning efforts to become "pious subjects" (Mahmood [2005] 2011)—although these teachings tended to reinforce prevailing social norms. As several studies have pointed out, women's Islamic activism can contribute to reproducing dominant social norms without necessarily seeking to change them (Augis 2005; Janson 2016).

From the early 1990s, a growing number of female AEEMCI activists were not satisfied with closely following Islamic dogma and readily accepting dominant social norms. Instead, they relied on Qur'anic texts to defend their rights within Islam. In particular, this required better access to religious knowledge to distinguish accurately between "true" Islam and "traditional" Islam. Women were to become emancipated by struggling against ancestral customs and traditional practices that had not originated with Islam. Among the Dioula-Malinké community—the dominant Muslim group in Côte d'Ivoire-especially in the North and outside the cities, young teenage girls are usually 
taken out of school to help their mothers with domestic work or to be married. Most women depend economically on their husbands, and traditional models of womanhood are based on domesticity, motherhood, and obedience to male authority. Ethnocultural practices include familyarranged endogamous marriages, polygamy, female seclusion (purdah), and female genital mutilation (Launay 1982; LeBlanc 1999).

A proper application of Islamic precepts would allow Muslim women to emancipate themselves and enjoy their rights. As Badran (2009, 324-25) has explained, "It is not about the reforming of patriarchal claims and practices insinuated into Islam; it is rather about the transforming of what has passed as 'Islam' through a realignment of Islam with the Qur'anic message of human equality and social justice." Nevertheless, these activists did not challenge aspects of Islam itself or support the achievement of full gender equality. They primarily addressed gender relations in terms of gender complementarity and therefore acknowledged differences between men and women. They were careful to avoid conflicts with the AEEMCI's male activists.

Maconi Cissé, one of the most visible and best-known Muslim women in Côte d'Ivoire during the 1990s, was a leading figure in this new cohort of female activists. In addition to teaching history and geography at the Lycée classique d'Abidjan, she presided over the Association des Femmes Musulmanes de la Riviera III (Association of Muslim women of the Riviera III), a particularly dynamic neighborhood-based Islamic association in a wealthy part of Abidjan. Her husband's brothers, Djiguiba Cissé and Alpha Cissé, are well-known Muslim figures. ${ }^{5}$ Although she was not a member of the AEEMCI, she frequently spoke at women's activities organized by the association during the 1990s, including Muslim Women's Days, which is why she is considered today the "godmother of all generations of AEEMCI female activists." ${ }^{6}$ Her reputation was strengthened by her appointment as the first vice president of the Conseil National Islamique (National Islamic council) responsible for women’s affairs. In 1991, she helped establish the Association des Femmes 
Musulmanes de Côte d'Ivoire (Association of Muslim women of Côte d'Ivoire, or AFMCI), the country's first national women's Islamic association, which was officially recognized by the state in $1994^{7}$ (Fraternité Matin 1997; Le Jour 1996).

In 1992, Maconi Cissé gave the closing address at the fourth edition of Muslim Women's Days, where she spoke about the concept of women's emancipation in Islam, identifying two main obstacles to women's emancipation: the weight of cultural traditions, which were un-Islamic, and the influence of Western modernity, which weakened moral standards. She insisted that "women's emancipation in Islam" should not involve a "frantic appeal for equality with men"; rather, she argued that although men and women have the same religious duties in Islam, Islam does not regard women as equal to men in all situations (La Voie 1992; Plume Libre 1992). These ideas were well aligned with those held by leading female figures within the AEEMCI. For example, in 1997, the association's vice president dismissed the caricature of Muslim women as perpetually oppressed by male authority by pointing out that Islam guarantees many rights for women; however, like Maconi Cissé, she nuanced her remarks by stating that "men and women do not have absolute equality. That would be absurd. What they do have is a rational and realistic equality based on different physical and biological attributes" (Le Jour 1997).

For Maconi Cissé, a wealthy and well-married woman, engaging in the 1990s in public activities about the proper role of Muslim women was a way to promote herself at the expense of other female activists. Following in her footsteps, Aminata Kane Koné emerged at the turn of the 2000s as a leading figure of a new cohort: younger female AEEMCI activists who adopted a more critical approach to ideas surrounding women's equality and emancipation in Islam. 


\section{Aminata Kane Koné and the Denunciation of "Bissap Activism": Islam as an Instrument of Women's Emancipation}

Born in 1981, Aminata Kane Koné was raised in a family of ten children actively involved in the local Muslim community. Her father, who died when she was six years old, contributed to the opening of several madrasas in the Adjamé district of Abidjan; her mother was a member of the management committee of their neighborhood mosque. Aminata Kane Koné joined the AEEMCI in 1998 — the same year she began to wear the hijab—while she was a student at the Lycée scientifique de Yamoussoukro. By the following year, she had become president of the association's women's section in this institution. After obtaining her baccalaureate degree in 2000, she attended the Université d'Abobo-Adjamé in Abidjan and was appointed president of the AEEMCI's women's section of the university. Her marriage in 2001 with Bakary Koné, the AEEMCI's national vice president between 2000 and 2003, and the birth of her first child did not prevent her from continuing her studies. She went on to study in the Faculty of Odonto-stomatology at the Université Félix Houphouët-Boigny (UFHB), graduating as a qualified dental surgeon in 2013, when she earned her $\mathrm{PhD}$.

Although she did not hold a leadership position in the AEEMCI between 2000 and 2008, she frequently spoke at the association's conferences, seminars, and other activities in a period when Muslims were suffering numerous abuses. From the 2000 presidential elections (especially after the failed coup of September 2002) to the signing of the Ouagadougou agreement in 2007, government security forces targeted suspected rebel sympathizers, including Muslims. Mosques were raided, Muslim leaders arbitrarily arrested, and several imams assassinated (Miran-Guyon 2015). Members of the Fédération Estudiantine et Scolaire de Côte d'Ivoire (Student federation of Côte d'Ivoire) and other progovernment youth groups, such as the Jeunes Patriotes (Young patriots), perpetrated violence against Muslim students groups. In July 2002, the AEEMCI president survived an 
attempted murder (Cissé 2015). From 2008 to 2010, Aminata Kane Koné served as the AEEMCI’s vice president responsible for social and women's affairs at the national level, the highest position a woman can hold in the organization. She received funding from the Spanish Agency for International Development Cooperation to complete a master's degree in 2012 in project development, with a focus on empowerment and leadership. She is currently pursuing a master's degree in neuroscience and aspires to be a professor.

In line with her self-described "rebellious nature" (Kane Koné 2015), Aminata Kane Koné notably helped institute major changes in the AEEMCI. Low participation by female activists at mixed-gender activities remained an issue at the turn of the twenty-first century. A women's-affairs officer with the organization blamed the problem on a "mental block" among female members: “For them, speaking out or pondering big questions was men's business. They were content to simply prepare food and drink at activities" (Plume Libre 2001). For female activists, public display of modesty, religious humility, and deference to men were still the norm. Similarly to what LeBlanc was then observing in neighborhood-based Islamic association in Côte d'Ivoire, women "remained in a position of 'needing to be taught' the precepts of Islam and having their religious practice closely monitored by men who possessed formal religious training” (2014, 183).

Aminata Kane Koné's comments at the AEEMCI's National Islamic Training Seminar in 1998 took direct aim at the persistence of this patriarchal hierarchy within the association. Although it was the first time she had participated in the event, she was chosen to present the final resolutions adopted by female members. She declared that "we sisters no longer want to engage in bissap activism” (Kane Koné 2015), a reference to a popular juice made from dried hibiscus flowers. In other words, she was saying that the women of the AEEMCI were no longer satisfied with being relegated to kitchen duties. This colorfully expressed desire to find new roles for female activists and to defend their access to religious education provides a clear example of her feminism, even if she 
does not often use the term. While trying to be a pious subject by conforming to Islamic principles, she engages critically and publicly with religious texts and their interpretation to claim women's rights and equality much like proponents of feminism as defined by Miriam Cooke: "Feminism involves political and intellectual awareness of gender discrimination, a rejection of behaviors furthering such discrimination, and the advocacy of activist projects to end discrimination and to open opportunities for women to participate in public life” (2001, ix).

Unlike her predecessors, whose criticisms focused on cultural traditions, Aminata Kane Koné has openly challenged male Muslims’ patriarchal interpretations of Islam, especially with the appeal of Salafism to an increasing number of Muslim university students since the mid- to late 1990s. In the next decade, doctrinal differences among AEEMCI activists on mixed-gender activities, wearing the niqab, and other issues led to dissent and the creation of new Muslim student organizations (Madore 2016a, 429-31). Aminata Kane Koné did not hesitate to take aim at the male members who were standing in the way of the changes she sought:

People may well be religious and they may well be Muslims, but cultural and educational influences had led them to segregate women, to treat men differently, and to deny women a voice. Often, this approach is reflected in the behavior of certain brothers. They can only be described as macho. ... Because some of them had decided we were temptations for them, ... they claimed they could no longer teach sisters. And since I was president at the time [2008-2010], I said OK, we'll show these characters that we can also learn our religion without their help. .. . I don't see why I should have to worry about being a woman and not be able to learn my religion in the same way as a man. And the history of our religion teaches us that women have been at the forefront of many things. You need to avoid getting caught up in questions of gender. You need to stop telling yourself that there are things that you cannot do because you are a woman or that you do not have the right to do because you are a woman. (Kane Koné 2015) 
The call to Muslim women to produce their own Islamic knowledge without relying on men and to perform as religious authorities for themselves even though they do not have formal training in Islamic jurisprudence, exegesis, or theology echoes Britta Frede and Joseph Hill's concept of "performativity" (2014). As they have argued regarding Muslim women, "Anyone perceived to know more than those in her or his milieu may potentially act as an authoritative personality in that context, even if the same person might not act as authoritatively in the company of scholars. Thus, people of all educational and social backgrounds can potentially demonstrate Islamic knowledge and act as an authoritative figure" $(2014,152)$. When Aminata Kane Koné was in her senior year, with friends, she decided to assemble a women-only team for the $\mathrm{Al} \mathrm{Ilm}^{8}$ contest, a general- and Islamicknowledge trivia tournament organized by the AEEMCI. They wanted to show to male members that they could succeed on their own. They made it to the finals and won (Kane Koné 2015).

For Aminata Kane Koné, expanding women's access to Islamic and secular education is fundamental, as many misconceptions persist about Muslim women who wear the veil, even if the number of veiled women on university campuses and in administrative offices has increased since the 1990s in Côte d'Ivoire (LeBlanc 2000). According to her, many people do not understand that a young woman could decide to "wear the veil for the sake of Allah" because the veil is often assimilated to being a "hadja," a nickname primarily given to older Muslim women who have made a pilgrimage to Mecca. ${ }^{9}$ In a newspaper interview, she discussed the importance of knowledge for veiled women:

I want to stress the importance of achieving a skill level that forces people to look beyond your veil. ... The best way for a woman to distinguish herself is through the strength of her knowledge. ... Men will bow before your knowledge. Knowledge will ensure that you can get things done, that you will have money, that you will be a good wife, daughter, colleague. Knowledge is a woman's most precious possession. You can be extremely beautiful, but if you behave atrociously 
toward others, no one will notice your beauty. But your knowledge will open doors for you even if you are dressed in rags. (Islam Info 2018)

In 2019, Aminata Kane Koné was invited to discuss feminism on an episode of Affaires de femmes (Women's Affairs), a series broadcast on the EDAN television network. During the debate, she explained that she "fully identified" with the definition put forward by Anglo-Irish author Rebecca West. She quoted her as saying, "I myself have never been able to find out what feminism is; I only know that people call me a feminist whenever I express sentiments that differentiate me from a doormat or a prostitute." Aminata Kane Koné added that, contrary to popular belief, the feminist struggle is not antithetical to wearing the veil: "As a veiled woman, ... I have the right to express myself. I have the right to receive a quality education. I have the right to earn as many diplomas and degrees as I want, and to live my life as I see fit, while naturally taking my religious faith into account." In this regard, she stressed the importance of rejecting the "Western approach" that "we have imported from elsewhere," is "atheist," and "does not belong to us" (EDAN 2019).

\section{From AEEMCI Activist to Islamic Radio Host and Media Entrepreneur}

Aminata Kane Koné's talents as a public speaker, which she displayed at numerous women’s activities organized by the AEEMCI, did not go unnoticed. Her experiences with the association served as a springboard for her career at Al Bayane, an Islamic radio station that began broadcasting in Abidjan and the surrounding area in November 2001, before expanding to other regions of Côte d'Ivoire. Today, it reaches more than 95 percent of the population and broadcasts twenty-four hours a day (Cissé 2014). Since 2005, its signal has been streaming online. ${ }^{10}$ Even if contemporary African mediascapes have been characterized by a proliferation of religious radio stations and TV channels (Grätz 2011; Hackett and Soares 2014; Meyer and Moors 2006), Al Bayane has reached exceptional popularity in Côte d'Ivoire. In fact, according to a study conducted in 2018, it is the most popular 
radio station in the country, with more listeners than any other religious or secular radio station (Jeune Afrique 2019).

Fousséni Diabaté, Al Bayane's anchorman and a former member of the AEEMCI, recommended Aminata Kane Koné to the station manager because she had "the potential to be a good communicator" (Kane Koné 2015). Of late, the new media entrepreneurs who are emerging in Africa, many of them young people, often have no formal job training in communication and media production (Grätz 2011, 2013). For instance, station manager Djiguiba Cissé and his team have pursued a strategy of recruiting young Muslims — both men and women-who do not necessarily have a background in journalism, communication, or even Islamic studies. Rather, these recruits have demonstrated eloquence and "good morals" by participating in activities organized by associations (Cissé 2014). Islamic radio stations throughout sub-Saharan Africa have found that programs featuring discussions, debates, and public interactions — such as live talk shows hosted by young people, including women—-tend to be popular in general and with younger listeners in particular (Adama 2014; Haron 2014). Al Bayane has capitalized on this type of programing.

Aminata Kane Koné, who was hired in 2007, seized the opportunity to become one of the station's most famous personalities. Between 2007 and 2016, she hosted various radio shows and played a key role in Al Bayane's development, especially by hosting live programs involving listener interaction, which were uncommon at the time she began to work at Al Bayane. Few programs were broadcast live to make it possible to review the content before airing it. This was particularly the case with programs featuring younger hosts who had not completed any advanced Islamic studies, and those hosted by women (Savadogo and Gomez-Perez 2011). Aminata Kane Koné cohosted a live show called Vie de femmes (Women's lives) ${ }^{11}$ alongside Aïssata Diaby, ${ }^{12}$ the program director. In it, they addressed women's rights; education; couple relationships; violence against women; economy, employment, and empowerment; and other women's issues. 
Aminata Kane Koné perceived her work at $\mathrm{Al}$ Bayane as a personal vocation in the continuity of her Islamic activism as a member of the AEEMCI. It gave her the opportunity to talk about how Islam is a helpful resource that can help women overcome everyday life challenges. Vie de femmes also allowed her to invite her listeners to rethink societal gender norms and popular misconceptions about women and Islam. She sought to raise awareness on the "real" status of women according to Islam, and more broadly, the question of women's role in society, since the audience is not composed exclusively of Muslims (Kane Koné 2015).

For several years, Aminata Kane Koné cohosted La matinale d'Al Bayane (The Al Bayane Morning Show), a highly popular live talk show, alongside Fousséni Diabaté. Even if an increasing number of women are hosting (live) programs on Islamic radio stations in West Africa (GomezPerez 2016; Gomez-Perez and Ba 2015; Madore and Gomez-Perez 2016; Ndzovu 2019; Schulz 2012), most of them are usually preachers who address themes strictly related to Islam and women. By contrast, La matinale d'Al Bayane allowed Aminata Kane Koné to take part in current societal debates beyond issues related to Islam. The hosts and their guests discussed a multitude of topics, both religious and secular, including national and international current affairs, such as Islam and abortion, social media, homosexuality, food safety, and academic success factors. Aminata Kane Koné and Fousséni Diabaté maintained a close relationship with their audience, constantly encouraging listeners to join the conversation via telephone, text messages, or Facebook. At the radio station, they launched the Dédicace de l'internaute (Dedication of the internet user). Every Saturday, a presenter reads selected messages from the station's Facebook page, ${ }^{13}$ which now has more than 208,000 followers. This interactivity greatly contributed to the program's success.

As a media-savvy entrepreneur, Aminata Kane Koné has cultivated a strong personal presence on the internet. Since the creation of her Facebook page in 2009, she has branded herself on social media reaching new publics. She has built an image of a young and pious Muslim public 
intellectual who has managed to conciliate her household responsibilities (She is the mother of eight children.) and work as a dental surgeon and a radio host—for which she is receiving much praise from her admirers, both male and female. Frequently asked about how she manages to do her professional work while raising such a large family, she has consistently stressed the value of effective time management, a frequent topic of her public talks. She emphasizes the importance of having an understanding husband — who is now the main imam of the Agitel-Formation mosque in Abidjan and the president of the Ruqya ${ }^{14}$ Cell in Côte d'Ivoire- - and the fact that all her sons regularly help with household tasks.

Over the years, Aminata Kane Koné has posted online several pictures of herself that regularly get a thousand "likes" and a hundred comments, often related to her beauty and her pious fashion. In response to her loyal following, she prepared a collection of her social media posts, organized by themes. As a result, her first book, Des mots pour apaiser (Words to appease), was published in 2017 by An-Nour World Space, a publishing house run by her husband. With more than 33,000 Facebook followers, ${ }^{15}$ she is one of the few, or perhaps the only, Ivorian Muslim woman to have reached such popularity on the internet (Binaté 2017b; Madore 2016b). ${ }^{16}$ When she announced her departure from Al Bayane on her Facebook page in March 2016, the news was greeted by 709 comments expressing both indignation and best wishes. In her message, she railed against her "unfair dismissal"— - under the pretext of her double status as civil servant (dental surgeon at the UFHB) and journalist ${ }^{17}$ — and took the opportunity to report certain issues with station management. ${ }^{18}$

Besides her work experience at Al Bayane, Aminata Kane Koné has maintained an active media presence through various initiatives. She has been a member of the Union Nationale des Journalistes de Côte d'Ivoire (National Union of Journalists of Côte d'Ivoire) since 2015. She has been interviewed several times_on the Islamic TV show Allabou Akbar on the RTI channel, the public 
television provider, and even on various TV variety shows, such as C'midi (2015), ${ }^{19}$ 100\% Femme (2018), ${ }^{20}$ Affaires de Femmes (2019), ${ }^{21}$ and La Télé d'Ici (2020). ${ }^{22}$ Other than being a media entrepreneur, she has established herself as an activist for social causes beyond the religious sphere, especially the promotion of entrepreneurship among young women and men.

\section{An Ivorian Success Story at the White House: Aminata Kane Koné's Advocacy Work for Youth Entrepreneurship}

"Doing good," overcoming social injustices, and promoting the good values of Islam have been the major aims of Aminata Kane Koné's entrepreneurial activities in recent years. She has been heavily involved in several projects promoting women's rights, Muslim and non-Muslim, as well as other initiatives related to education and employment. Collaborating with seven NGOs and associations, she initiated a project to support the adoption of a charter of good conduct regarding sexual violence and abuse against girls in schools (Kane Koné 2015).

Her expanding professional network with United States representatives in Côte d'Ivoire and abroad has opened new opportunities for her. The American embassy in Côte d'Ivoire has taken note of her social-engagement and volunteer work. In 2010, she was named Ivorian ambassador for Nouveaux Horizons (NH), a publishing house run by the Africa Regional Services of the US State Department. The NH imprint publishes books by American authors translated into French for sale and distribution in francophone Africa, the Maghreb, and Haiti. ${ }^{23}$ To be selected, candidates must have shown a proven commitment to their community through volunteering or mentoring for children, youth, women, or other segments of the population. In 2018, in partnership with NH, Aminata Kane Koné opened a children's reading center called Ici on LIT ensuite on JOUE (Here we READ and then we PLAY). ${ }^{24}$ The center aims to inspire a love of reading in young children while helping them overcome learning difficulties. In 2019, she left her volunteer position as an Ivorian ambassador for $\mathrm{NH}$ to become an $\mathrm{NH}$ bookseller. 
Among all her achievements, her invitation to the White House is probably the one that has contributed the most to her fame in Côte d'Ivoire. In 2010, to mark the fiftieth anniversary of many African countries gaining their independence, US President Barack Obama invited some one hundred young people, among whom was Aminata Kane Koné, to the President's Forum with Young African Leaders in Washington, DC. This meeting led to the creation of the Young African Leaders Initiative, designed to support "young African leaders as they work to spur growth and prosperity, strengthen democratic governance, and enhance peace and security across the continent" (The White House 2013). In an address to the invited leaders, President Obama personally congratulated Aminata Kane Koné for her advocacy work for Muslim women’s rights, "rights that are sometimes denied by men” (Kane Koné 2015). In 2011, she was invited to Johannesburg, South Africa, to participate in the First Lady's Young African Women Leaders Forum, where she met Michelle Obama.

When Aminata Kane Koné came back from the United States in 2010, she wanted to share her experience with as many young Ivorians as possible. Therefore, she founded the Facebook group "Young African Leaders Côte d'Ivoire" (YALCI). ${ }^{25}$ YALCI was active mostly on social media before it became a formal organization in June 2013. Since then, she has presided over this network, which promotes leadership, entrepreneurship, and volunteerism among youth and encourages them "to play their part in the development of a new Africa" (Kane Koné 2015). YALCI has organized numerous debates on different themes related to young people's lives, such as the role of the youth for ensuring a peaceful presidential election in 2010, youth and national reconciliation following the postelectoral crisis, ${ }^{26}$ journalism, corruption, HIV/AIDS, and reintegration of former combatants.

In addition to being regularly solicited by the US embassy as a moderator, speaker, and trainer in public speaking, Aminata Kane Koné is a frequent guest speaker for the AEEMCI, especially since its activists have been showing increased interest in entrepreneurship and 
socioeconomic development. In recent years, as with other Islamic associations, many AEEMCI activities have dealt with Muslims and "An emerging Côte d'Ivoire looks forward to 2020," a $\operatorname{slogan}^{27}$ regularly used by President Ouattara. Youth and women figured prominently in his Plan National de Développement (National development plan). For example, in 2016, the theme for the AEEMCI Female Activists’ Day was “Leadership and Entrepreneurship among Women: Benefits for a Society Working toward Emergence." Participants had the chance to attend two training workshops: "Female Excellence in Support of Emergence" and "How to Launch a Business Project” (Islam Info 2016). In 2017, Aminata Kane Koné was the keynote speaker at the twelfth AEEMCI Female Activists' Day for a talk on a similar topic.

Aminata Kane Koné has contributed to raising issues she saw as important to women's emancipation, including self-realization, entrepreneurship, financial independence, professional opportunities, and the gender pay gap. In a televised debate in 2019, she stressed the importance of teaching young women to "avoid taking the easy road by telling themselves that, "As a young woman, I simply need to make myself pretty, to be charming, and to catch the eye of a man who will marry me. Then, I'll enjoy an easy life at home"' (EDAN 2019). Although she has expressed admiration for women who choose to stay at home, she has nevertheless encouraged them to set aside some of their time for online learning, so they can find employment if they ever want or need to. In the same vein, she reminded her audience during a talk in 2018 that "the wife is responsible for taking care of her home," but "it is not a matter of saddling the wife with so many household responsibilities that she is deprived of any active role in society, and that society is deprived of her contributions." ${ }^{28}$ By initiating all these entrepreneurial projects and activities, she has become an agent of religious, gender, and social transformations while becoming a female frgure of success in the process. 


\section{Conclusion}

Although Aminata Kane Koné does not represent the average of less privileged women in rural areas in Côte d'Ivoire, who cannot benefit from opportunities offered by urban life, her career path is remarkable in more than one respect. She has emerged as a female success story in a context where the possibilities for social climbing are usually constrained for young Muslim women. She has established herself as a successful religious entrepreneur active at the intersections of religion, media, and economic and social activities. Despite having no formal training in Islamic studies, she has claimed the right to teach and interpret Islamic texts based on her knowledge, charisma, pious image, and commitment to social issues.

Aminata Kane Koné has contributed significantly to curtailing the male domination of religious leadership within the AEEMCI. Even though women were long involved in the AEEMCI, and it organized gender-based activities from its start, in the 1970s, female activists largely

conformed to traditional religious teachings that maintained dominant social norms without seeking to change them. Things began to change in the 1990s, when some female activists started using Qur'anic texts to defend their rights in the face of local customs and traditions. From the moment Aminata Kane Koné joined the AEEMCI, in 1998, to the end of her mandate as the vice president responsible for social and women's affairs at the national level, in 2010, she renegotiated power relations within the Islamic organization. While striving to become a pious subject, she adopted a critical approach to religion in support of women's political, social, and economic rights from a feminist perspective. She exposed the inequities in sustaining a patriarchal interpretation of Islamic texts and did not hesitate to defy misogynistic AEEMCI's male activists openly. She stressed the importance of Muslim women producing their own Islamic knowledge and strongly advocated for women's self-realization, entrepreneurship, and financial independence. 
Her Islamic activism allowed her to launch a career as a media entrepreneur. The managers of the Islamic radio station $\mathrm{Al}$ Bayane had started to recruit more young people and, in some cases, women, who made up for their lack of formal training in communication and Islamic studies with a high degree of eloquence and charisma. Hired in 2007, she established herself as one of the most famous Islamic radio presenters by hosting live talk shows. She has become much admired for her views expressed on Islam and women, as well as on nonreligious topics. Her engagement with social media has played a key role in the making of her career. By using Facebook actively, she has mobilized a growing community of followers and sympathizers, both women and men. She has distinguished herself as an entrepreneur by launching initiatives related to women's rights and youth entrepreneurship. The support and praise she has received from US authorities have further consolidated her position as a leading female Muslim public intellectual in Côte d'Ivoire and as a role model for Muslim women and young Ivorians.

Through her actions and entrepreneurship, Aminata Kane Koné has claimed a meaningful Islamic identity, capable of contributing to the ongoing transformation of religious practices and the socioeconomic development of her country. Her career path seriously undermines the image of Muslim women perceived as passive, oppressed, and "in need of saving" (Abu-Lughod 2013), often propagated by the rhetoric of salvation in some Western media and human-rights discourses. Islamic piety can be compatible with the ideas of women's rights and equality. Her case highlights how Muslim women in sub-Saharan Africa are too often overlooked in research on Islam and feminism.

\section{Acknowledgments}

I thank the three reviewers for their insightful comments, and Yssoufou Traoré for his assistance during the fieldwork. This article is based on research funded by a Joseph-Armand Bombardier Canada Graduate Scholarships Program Doctoral Scholarship and a Banting Postdoctoral Fellowship (Social Sciences and Humanities Research Council of Canada). 


\section{Notes}

1. The second-largest city in Côte d'Ivoire, located in the central part of the country.

2. Fraternité Matin, La Voie, and Le Jour.

3. Plume Libre and Islam Info.

4. All quotations from French-language sources were translated by Steven Watt.

5. Djiguiba Cissé is the station manager of the Islamic radio Al Bayane and the imam of the Plateau Mosque in Abidjan. The late Alpha Cissé published an annual calendar of Islamic holidays (Calendrier Alpha) based on astronomical calculations, rather than the usual observations of the Moon.

6. Facebook post from December 6, 2015 on the page “Aeemci Comité Exécutif”:

https://www.facebook.com/permalink.php?story fbid=1284406711585070\&id=622883921070689.

7. From 1997 to 2014, the AFMCI was presided over by Mariam Fofana, a retired accountant, who was working at the National Society of Petroleum Operations in Côte d'Ivoire. Her seventeen-year term without holding a general assembly to elect a new executive council blocked the promotion of younger female activists in this association.

8. "The knowledge" in Arabic.

9. On how the honorific name hadja, from the Arabic word hajj, is used in popular parlance to refer to young Muslim women who wear the veil, see Ouedraogo 2019.

10. See their website: www.albayane.ci.

11. Titled Femmes et société (Women and society) before May 2013.

12. She was previously married to the lawyer, writer, professor, and politician Ibrahim Bacongo

Cissé, who has held several cabinet portfolios since 2005.

13. As of November 15, 2020 (https://www.facebook.com/radioalbayane).

14. Treatment against black magic, jinn possession, and evil eye.

15. As of November 23, 2020 (https://www.facebook.com/kaneaminata.kone). 
16. A notable exception is the twenty-six-year-old professor, blogger, and social entrepreneur, Tchonté Pitin Mireille Silué. This Muslim convert, who claims to be a feminist, was the winner of the "best blogger in Côte d'Ivoire" in 2017 (https://leschroniquesdetchonte.com) and was recognized as one of the most influential young Ivorians in 2019.

17. The "real" reasons of her dismissal are publicly unknown.

18. See her Facebook post of March 18, 2016:

https://www.facebook.com/kaneaminata.kone/posts/1214334655251309.

19. See RTI 2015.

20. See RTI 2018.

21. See EDAN 2019.

22. See NCI 2020.

23. See Ambassade, n.d.

24. See its Facebook page at: https://www.facebook.com/Ici-on-LIT-ensuite-on-JOUE$\underline{554249444945454 .}$

25. See their Facebook page at: https://www.facebook.com/YOUNG-AFRICAN-LEADERSCOTE-DIVOIRE-170273843028471.

26. The results of the second round of the 2010 presidential election, the first in a decade, resulted in an electoral dispute. Both candidates claimed victory. Laurent Gbagbo, the incumbent president, was recognized by the Constitutional Council; Alassane Ouattara was recognized by the Independent Electoral Commission and the international community.

27. "Faire de la Côte d'Ivoire un pays émergent à l’horizon 2020."

28. See her Facebook post of May 28, 2018:

https://www.facebook.com/kaneaminata.kone/videos/vb.100000243582170/2261192463898851. 


\section{References Cited}

Abu-Lughod, Lila. 2013. Do Muslim Women Need Saving? Cambridge: Harvard University Press.

Adama, Hamadou. 2014. "Islamic Communication and Mass Media in Cameroon." In New Media and Religious Transformations in Africa, edited by Rosalind I. J. Hackett and Benjamin F. Soares, 137-56. Bloomington: Indiana University Press.

Akindès, Francis. 2017. “'On ne mange pas les ponts et le goudron’: Les sentiers sinueux d’une sortie de crise en Côte d'Ivoire." Politique africaine, no. 148, 5-26.

Akindès, Francis, and Virginie Troit. 2017. "Introduction: La transition humanitaire en Côte d'Ivoire, éléments de cadrage." In Transition humanitaire en Côte d'Ivoire, edited by Thomas Fouquet and Virginie Troit, 9-24. Paris: Karthala.

Ambassade et consulats des Etats-Unis d'Amérique en France. n.d. "Editions Nouveaux Horizons." Last accessed November 18, 2020. https://fr.usembassy.gov/fr/ars-paris-fr/livres/nh/.

Augis, Erin. 2005. “Dakar's Sunnite Women: The Politics of Person.” In L'Islam politique au sud du Sahara: Identités, discours et enjeux, edited by Muriel Gomez-Perez, 309-26. Paris: Karthala.

Badran, Margot. 2009. Feminism in Islam: Secular and Religious Convergences. London: Oneworld.

Banégas, Richard, and Jean-Pierre Warnier. 2001. "Nouvelles figures de la réussite et du pouvoir." Politique africaine, no. 82, 5-23.

Bierschenk, Thomas, Jean-Pierre Chauveau, and Jean-Pierre Olivier de Sardan, eds. 2000. Courtiers en développement: Les villages africains en quête de projets. Paris: Karthala.

Binaté, Issouf. 2016. "Muslim NGOs in Côte d'Ivoire: Towards an Islamic Culture of Charity.” In Faith and Charity: Religion and Humanitarian Assistance in West Africa, edited by Marie Nathalie LeBlanc and Louis Audet Gosselin, 47-62. London: Pluto. 
—. 2017a. "Les célébrations du Maouloud au nord de la Côte-d’Ivoire: Entre espace de réislamisation, socialisation et quête de légitimité politique." Cabiers d'études africaines 57 (225): $39-58$.

—. 2017b. "Les Musulmans de Facebook en Côte d'Ivoire: Nouvelle voie de socialisation, de da'wa et de mobilisation communautaire." Émulations, no. 24, 53-70.

Cooke, Miriam. 2001. Women Claim Islam: Creating Islamic Feminism through Literature. London: Routledge.

Diouf, Mamadou S., and Steven Rendall. 2000. “The Senegalese Murid Trade Diaspora and the Making of a Vernacular Cosmopolitanism.” Public Culture 12 (3): 679-702.

EDAN. 2019. “Affaires de femmes: féminisme.” YouTube video, 26:46. Posted by “EDAN,” November 5, 2019. https://youtu.be/bQOBXomk-cM.

Fourchard, Laurent, André Mary, and René Otayek, eds. 2005. Entreprises religieuses transnationales en Afrique de l'Ouest. Paris: Karthala.

Fraternité Matin. 1974. “M. Losséni Zoromé, président de la Jeunesse Estudiantine Musulmane.” May $16,1974$.

_. 1978. 'La jeune fille musulmane face à la vie moderne: 'Obéissance, pudeur, respect' déclare El Hadj Souleymane Doumbia au cours d'un dîner-débat.” December 22, 1978, 17.

—. 1989a. “A.E.E.M.C.I.: Du 23 au 27 mars 2èmes journées de la femme musulmane.” March 23, 1989.

—. 1989b. "2èmes journées de la femme musulmane: CEuvrer au renforcement de l’œcuménisme.” April 5, 1989.

—. 1997. “1er Congrès ordinaire de l’Afmci: L’œuvre sociale de Mme Bédié saluée.” July 29, 1997. 
Frede, Britta, and Joseph Hill. 2014. "Introduction: En-Gendering Islamic Authority in West Africa." Islamic Africa 5 (2): 131-65.

Freeman, Dena, ed. 2012. Pentecostalism and Development: Churches, NGOs and Social Change in Africa. Basingstoke: Palgrave Macmillan.

Gomez-Perez, Muriel. 2016. “Women’s Islamic Activism in Burkina Faso: Toward Renegotiated Social Norms?" Canadian Journal of African Studies / Revue canadienne des études africaines 50 (1): $45-63$.

Gomez-Perez, Muriel, and Selly Ba. 2015. "Les prédicatrices au Sénégal: De la visibilité à la légitimité religieuse et sociale (des années 1980 à nos jours).” In État, Sociétés et Islam au Sénégal: un air de nouveau temps?, edited by Abdourahmane Seck, Mayke Kaag, Cheikh Guèye, and Abdou Salam Fall, 175-203. Paris: Karthala.

Grätz, Tilo. 2011. “Contemporary African Mediascapes: New Actors, Genres and Communication Spaces." Journal of African Media Studies 3 (2): 151-60.

—. 2013. "New Media Entrepreneurs and Changing Styles of Public Communication in Africa: Introduction." Journal of African Cultural Studies 25 (1): 1-13.

Hackett, Rosalind I. J., and Benjamin F. Soares. 2014. "Introduction: New Media and Religious Transformations in Africa." In New Media and Religious Transformations in Africa, edited by Rosalind I. J. Hackett and Benjamin F. Soares, 1-16. Bloomington: Indiana University Press. Haenni, Patrick. 2005. L'Islam de marché: L’autre révolution conservatrice. Paris: Seuil. Hafez, Sherine. 2011. An Islam of Her Own: Reconsidering Religion and Secularism in Women's Islamic Movements. New York: New York University Press.

Haron, Muhammed. 2014. "Muslim Community Radio Stations: Constructing and Shaping Identities in a Democratic South Africa." In New Media and Religious Transformations in Africa, edited by 
Rosalind I. J. Hackett and Benjamin F. Soares, 82-96. Bloomington: Indiana University Press.

Hill, Joseph. 2017. “Charismatic Discipleship: A Sufi Woman and the Divine Mission of Development in Senegal." Africa 87 (4): 832-52.

- 2018. Wrapping Authority: Women Islamic Leaders in a Sufi Movement in Dakar, Senegal. Toronto: University of Toronto Press.

Ibrahima, B. A, dir. 2014. "Recensement général de la population et de l’habitat 2014: Rapport d'exécution et présentation des principaux résultats." Institut national de la statistique. www.ins.ci/n/documents/RGPH2014 expo dg.pdf.

Islam Info. 2016. “Journées de la Militante Aeemciste d'Abidjan-sud: Les sœurs invitées à l'entrepreneuriat." May 18-24, 2016, 5.

—. 2018. "Brave femme: Koné Aminata Kane; Une femme multidimensionnelle grâce à son amour pour la lecture.” November 21, 2018, 15.

Jalloh, Alusine, and Toyin Falola, eds. 2002. Black Business and Economic Power. Rochester, NY: University of Rochester Press.

Janson, Marloes. 2016. "Male Wives and Female Husbands: Reconfiguring Gender in the Tablighi Jama 'at in The Gambia." Journal of Religion in Africa 46 (2/3): 187-218.

Jeune Afrique. 2019. "Côte d'Ivoire: Radio Nostalgie conserve sa place de première radio commerciale.” March 28, 2019. https://www.jeuneafrique.com/755059/economie/cotedivoire-radio-nostalgie-conserve-sa-place-de-premiere-radio-commerciale/.

Kane Koné, Aminata. 2017. Des mots pour apaiser. Abidjan: An-Nour World Space.

Launay, Robert. 1982. Traders without Trade: Responses to Change in Two Dyula Communities. Cambridge: Cambridge University Press. 
Lauterbach, Karen. 2015. "Religious Entrepreneurs in Ghana.” In Cultural Entrepreneurship in Africa, edited by Ute Röschenthaler and Dorothea E. Schulz, 19-36. New York: Routledge.

La Voie. 1992. “Islam: La femme musulmane à l'honneur.” April 14, 1992.

LeBlanc, Marie Nathalie. 1999. "The Production of Islamic Identities through Knowledge Claims in Bouaké, Côte d'Ivoire.” African Affairs 98 (393): 485-508.

- 2000. "Versioning Womanhood and Muslimhood: 'Fashion' and the Life Course in Contemporary Bouake, Côte d'Ivoire." Africa 70 (3): 442-81.

—. 2007. "Imaniya and Young Muslim Women in Côte d'Ivoire." Anthropologica 49 (1): 35-50.

—. 2012. "Du militant à l'entrepreneur: Les nouveaux acteurs religieux de la moralisation par le bas en Côte-d'Ivoire.” Cabiers d'études africaines 52 (206/207): 493-516.

- 2014. "Piety, Moral Agency, and Leadership: Dynamics around the Feminization of Islamic Authority in Côte d'Ivoire." Islamic Africa 5 (2): 167-98.

- 2016. 'Precarious Agency in the Face of 'Good Governance': The NGO-isation of Muslim Women's Associations in Côte d'Ivoire." In Faith and Charity: Religion and Humanitarian Assistance in West Africa, edited by Marie Nathalie LeBlanc and Louis Audet Gosselin, 85104. London: Pluto.

Lefeuvre, Isaure, François Roubaud, Constance Torelli, and Claire Zanuso. 2017. "Insertion des jeunes sur le marché du travail en Côte d'Ivoire: La bombe à retardement est-elle dégoupillée?” Afrique contemporaine, no. 263/264, 233-37.

Le Jour. 1996. "Mme Cissé Maconi, vice-présidente du Conseil national islamique (CNI): 'La Musulmane est soumise, mais. ..." April 9, 1996, 7.

_. 1997. "Islam: Les femmes renforcent leur position." April 1, 1997.

Madore, Frédérick. 2016a. “The New Vitality of Salafism in Côte d’Ivoire: Toward a Radicalization of Ivoirian Islam?" Journal of Religion in Africa 46 (4): 417-52. 
—. 2016b. “L'Islam ivoirien et burkinabé à l'ère du numérique 2.0.” Journal des anthropologues, no. 146/147, 151-78.

Madore, Frédérick, and Muriel Gomez-Perez. 2016. "Muslim Women in Burkina Faso since the 1970s: Toward Recognition as Figures of Religious Authority?” Islamic Africa 7 (2): 185-209.

Mahmood, Saba. (2005) 2011. Politics of Piety: The Islamic Revival and the Feminist Subject. Princeton, NJ: Princeton University Press.

Marshall, Ruth. 2009. Political Spiritualities: The Pentecostal Revolution in Nigeria. Chicago: University of Chicago Press.

Meyer, Birgit, and Annelies Moors, eds. 2006. Religion, Media, and the Public Sphere. Bloomington: Indiana University Press.

Miran, Marie. 2006. Islam, histoire et modernité en Côte d'Ivoire. Paris: Karthala.

Miran-Guyon, Marie. 2015. Guerres mystiques en Côte d'Ivoire: Religion, patriotisme, violence (2002-2013). Paris: Karthala.

—. 2017. "Société musulmane et régime Ouattara en Côte d’Ivoire: Des affinités électives en demi-teinte." Afrique contemporaine, no. 263/264, 249-54.

Miran-Guyon, Marie, and Nurudine Oyewolé. 2015. "Côte d'Ivoire, un Islam d'expression française à la fois tangible et restreint." Histoire, monde et cultures religieuses 36 (4): 141-58.

NCI. 2020. "La télé d'ici du 21 Janvier 2020; Invités: Dr Aminata Kane, Tchonté Mireille et Fusion Band.” YouTube video, 1:06:51. Uploaded by “La Nouvelle Chaîne Ivoirienne,” January 22, 2020. https://youtu.be/iNrGWiAdALE.

Ndzovu, Hassan J. 2019. "Broadcasting Female Muslim Preaching in Kenya: Negotiating Religious Authority and the Ambiguous Role of the Voice." African Journal of Gender and Religion 25 (2): 14-40. 
Osella, Filippo, and Caroline Osella. 2009. "Muslim Entrepreneurs in Public Life between India and the Gulf: Making Good and Doing Good." Journal of the Royal Anthropological Institute 15 (1): 202-21.

Ouedraogo, Lassane. 2019. "Muslim Women and Pious Fashion in Burkina Faso as Identity, Pose, and Defiance." The Communication Review 22 (4): 271-95.

Plume Libre. 1992. “La femme musulmane à l'honneur à Dabou.” May 1992, 5.

—. 2001. "Journées de la femme musulmane du 13 au 17 avril 2001 à Agboville: Les femmes de l'AEEMCI se mobilisent pour contribuer à l'édification de la nation.” April 6-12, 2001, 2. Rinaldo, Rachel. 2013. Mobilizing Piety: Islam and Feminism in Indonesia. Oxford: Oxford University Press.

Röschenthaler, Ute, and Dorothea E. Schulz. 2015. "Introduction: Forging Fortunes; New Perspectives on Entrepreneurial Activities in Africa." In Cultural Entrepreneurship in Africa, edited by Ute Röschenthaler and Dorothea E. Schulz, 1-15. New York: Routledge.

RTI. 2015. “C'midi de RTI 1 du 24 décembre 2015 avec Caroline Dasylva Partie 2.” YouTube video, 25:38. Uploaded by “RTI Officiel," December 24, 2015. https://youtu.be/1jE zNAAMQQ.

—. 2018. “100\% FEMME de RTI 2 du 15 Juin 2018 avec Aminata KANE KONE par Christelle MELEDJE l'intégrale." YouTube video, 26:42. Uploaded by "RTI Officiel," June 18, 2018. https://youtu.be/rQh2IlCSxd0.

Saint-Lary, Maud. 2019. Réislamisations au Burkina Faso: Questions de genre et enjeux sociaux. Paris: Karthala.

Savadogo, Mathias, and Muriel Gomez-Perez. 2011. "La médiatisation des prêches et ses enjeux: Regards croisés sur la situation à Abidjan et à Ouagadougou." Ethnographiques.org, no. 22. https://www.ethnographiques.org/2011/Savadogo-Gomez-Perez. 
Schielke, Samuli. 2010. "Second Thoughts about the Anthropology of Islam, or How to Make Sense of Grand Schemes in Everyday Life." ZMO Working Papers 2, Zentrum Moderner Orient, Berlin. https://d-nb.info/1019243724/34.

Schulz, Dorothea E. 2012. Muslims and New Media in West Africa: Pathways to God. Bloomington: Indiana University Press.

Soares, Benjamin F. 2005. Islam and the Prayer Economy: History and Authority in a Malian Town. Edinburgh: Edinburgh University Press.

- 2016. "New Muslim Public Figures in West Africa." In Islamic Education in Africa: Writing Boards and Blackboards, edited by Robert Launay, 268-84. Bloomington: Indiana University Press.

- 2017. “'Structural Adjustment Islam’ and the Religious Economy in Neoliberal Mali.” In Religion and the Morality of the Market, edited by Filippo Osella and Daromir Rudnyckyj, 13859. Cambridge: Cambridge University Press.

Soares, Benjamin, and Marie Nathalie LeBlanc. 2015. "Islam, jeunesse et trajectoires de mobilisation en Afrique de l'Ouest à l'ère néoliberale: Un regard anthropologique.” In Collective Mobilisations in Africa / Mobilisations collectives en Afrique: Enough is enough! / Ca suffit!, edited by Kadya Tall, Marie-Emmanuelle Pommerolle, and Michel Cahen, 67-90. Leiden: Brill. Sounaye, Abdoulaye. 2013. "Alarama is All at Once: Preacher, Media 'Savvy', and Religious Entrepreneur in Niamey.” Journal of African Cultural Studies 25 (1): 88-102.

—. 2015. "Let's Do Good for Islam: Two Muslim Entrepreneurs in Niamey, Niger." In Cultural Entrepreneurship in Africa, edited by Ute Röschenthaler and Dorothea E. Schulz, 3757. New York: Routledge.

Taura, Nasiru D., Elvira Bolat, and Nnamdi O. Madichie, eds. 2019. Digital Entrepreneurship in SubSaharan Africa: Challenges, Opportunities and Prospects. Cham, Switzerland: Palgrave Macmillan. 
The White House. 2013. “Fact Sheet: The President's Young African Leaders Initiative.” June 29, 2013. https://obamawhitehouse.archives.gov/the-press-office/2013/06/29/fact-sheetpresident-s-young-african-leaders-initiative.

\section{Interviews}

Cissé, Djiguiba. 2014. Interview by the author, December 10, 2014. Abidjan, Côte d'Ivoire.

Cissé, Mohamed. 2015. Interview by the author, January 13, 2015. Abidjan, Côte d'Ivoire.

Doumbia, Ibrahim. 2015. Interview by the author, March 12, 2015. Abidjan, Côte d'Ivoire.

Kane Koné, Aminata. 2015. Interview by the author, March 26, 2015. Abidjan, Côte d'Ivoire.

Koné, Mamadou, 2014. Interview by the author, November 24, 2014. Abidjan, Côte d'Ivoire.

FRÉDÉRICK MADORE is a Postdoctoral Research Fellow at the Leibniz-Zentrum Moderner Orient (ZMO). He has conducted extensive fieldwork in Côte d'Ivoire, Burkina Faso, Benin, and Togo, focusing on Islamic activism among youth and women, their appropriation of (new) media, and Muslim politics. He is the author of the book La construction d'une sphère publique musulmane en Afrique de l'Ouest (Presses de l'Université Laval / Hermann, 2016) on Islam in Burkina Faso. 